\title{
Quantitative proteomic analysis of sphere-forming stem-like oral cancer cells
}

\author{
Kaori Misuno ${ }^{1,2}$, Xiaojun $\mathrm{Liu}^{1,2}$, Sizhe Feng ${ }^{1,2}$ and Shen $\mathrm{Hu}^{1,2^{*}}$
}

\begin{abstract}
Introduction: The purpose of this study is to identify target proteins that may play important functional roles in oral cancer stem-like cells (CSCs) using mass spectrometry-based quantitative proteomics.

Methods: Sphere-formation assays were performed on highly invasive UM1 and lowly invasive UM2 oral cancer cell lines, which were derived from the same tongue squamous cell carcinoma, to enrich CSCs. Quantitative proteomic analysis of CSC-like and non-CSC UM1 cells was carried out using tandem mass tagging and two-dimensional liquid chromatography with Orbitrap mass spectrometry.

Results: CSC-like cancer cells were found to be present in the highly invasive UM1 cell line but absent in the lowly invasive UM2 cell line. Stem cell markers SOX2, OCT4, SOX9 and CD44 were up-regulated, whereas HIF-1 alpha and PGK-1 were down-regulated in CSC-like UM1 cells versus non-CSC UM1 cells. Quantitative proteomic analysis indicated that many proteins in cell cycle, metabolism, G protein signal transduction, translational elongation, development, and RNA splicing pathways were differentially expressed between the two cell phenotypes. Both CREB-1-binding protein (CBP) and phosphorylated CREB-1 were found to be significantly over-expressed in CSC-like UM1 cells.

Conclusions: CSC-like cells can be enriched from the highly invasive UM1 oral cancer cell line but not from the lowly invasive UM2 oral cancer cell line. There are significant proteomic alterations between CSC-like and non-CSC UM1 cells. In particular, CBP and phosphorylated CREB-1 were significantly up-regulated in CSC-like UM1 cells versus non-CSC UM1 cells, suggesting that the CREB pathway is activated in the CSC-like cells.
\end{abstract}

\section{Introduction}

Oral cancer, predominantly oral squamous cell carcinoma (OSCC), is the sixth most common human cancer worldwide. In the United States there were 39,400 new cases of oral cavity and pharynx cancer and 7,900 related deaths in 2011. Worldwide, however, there are more than 480,000 new cases annually [1]. Patients diagnosed with OSCC often present with symptoms at a late stage, and there is a high recurrence rate after treatment, especially in those with neck lymph node metastasis [2]. Despite clinical and treatment advances, the overall five-year survival rates for oral cancer have remained low and relatively unchanged during the past few decades [3,4]. The high mortality rate of oral cancer highlights the

\footnotetext{
* Correspondence: shenhu@ucla.edu

'School of Dentistry, University of California, Los Angeles, CA 90095, USA

${ }^{2} J o n s s o n$ Comprehensive Cancer Center, University of California, Los Angeles, CA 90095, USA
}

importance of studying the molecular and cellular mechanisms of this devastating disease.

Cancer stem cells (CSCs) comprise a small subpopulation of cancer cells that possess the capacity to selfrenew and to cause the heterogeneous lineages of cancer cells that comprise the tumor [5-7]. These cells appear to be responsible for tumor initiation and sustained growth, and their presence is believed to play an important role in tumor metastasis and resistance to chemotherapy or radiation therapy [8]. In this regard, studying CSC biology is critical for the discovery of novel therapeutic targets in human cancers. Enrichment and isolation of CSC-like cells have been made possible by using various methods including efflux of vital dyes by multidrug transporters (for example, ABC transporters), increased enzymatic activity (for example, aldehyde dehydrogenase, ALDH), sphere-forming assays, and cell surface expression of specific stem cell markers [9-14]. \\ C Biomed Central}


Prince et al. identified a $\mathrm{CD} 44^{+}$subpopulation from primary head and neck squamous cell carcinomas (HNSCC) that expressed basal cell markers, cytokeratin 5 and 14, and the stem cell marker BMI1. They found that as few as 5,000 CD44 ${ }^{+}$HNSCC cells gave rise to a new tumor when transplanted into the flank of immunocompromised mice, whereas CD44 cells failed to form tumors in the mice $[15,16]$. Clay et al. demonstrated that as few as 500 ALDH $^{\text {high }}$ cancer cells could form new HNSCC tumors in immunocompromised mice, ten-fold fewer cells than the CD $44^{+}$subpopulation. Most of the $\mathrm{ALDH}^{\text {high }}$ cells were also $\mathrm{CD} 44^{+}$. However, a small fraction of $\mathrm{ALDH}^{+}$cells remained $\mathrm{CD}_{44^{-}}$[12]. Oral CSC-like cells can also be isolated from OSCC using a sphere-formation assay by cultivating the cancer cells in serum-free medium with growth factors such as basic fibroblast growth factor (bFGF) and epidermal growth factor (EGF). Using this approach, Chiou et al. isolated oral CSC-like cells that expressed high levels of stem/progenitor cell markers, OCT-4, Nanog, CD117, Nestin, CD133, as well as ABC transporter ABCG2. The CSC-like cells also displayed induced differentiation abilities and enhanced migration and invasion potential. Positive correlations of OCT-4, Nanog, or CD133 expression with tumor stage were observed in OSCC patients, and Nanog/OCT-4/CD133 triple-positive patients had the worst survival prognosis [17]. Similarly, Zhang et al. identified a subpopulation of $\mathrm{CD} 133^{+}$CSC-like cells that possess higher clonogenicity, invasiveness and increased in vivo tumorigenicity when compared to $\mathrm{CD}_{133^{-}}$counterparts. Meanwhile, CD133 ${ }^{+}$ CSCs were substantially resistant to standard chemotherapy, in which both in vitro and in vivo treatment with paclitaxel resulted in a marked enrichment for CD $133^{+}$CSCs. These findings suggest that $\mathrm{CD} 133^{+}$cells represent a small subpopulation of CSCs that may contribute to chemoresistance in oral cancer [13].

cAMP responsive element binding protein 1 (CREB-1) is a transcription factor that binds to the cAMP response element, a DNA nucleotide sequence present in many viral and cellular promoters. The protein belongs to the leucine zipper family of DNA-binding proteins. Various serine/threonine kinases, such as ribosomal protein S6 kinase, protein kinase $\mathrm{C}$, protein kinase $\mathrm{B} / \mathrm{AKT}$, and mitogen- and stress-activated protein kinase (MSK-1), may activate CREB-1 in cells via phosphorylation [18]. Activated CREB-1 then recruits transcription co-activators $\mathrm{CREB}-1$-binding protein $(\mathrm{CBP}) / \mathrm{p} 300$ and relocates to the nucleus to activate a number of downstream targets, especially those genes involved in cell growth, survival and cell-cycle regulation. CREB-1 has been implicated in multiple human cancers as well as diverse cellular processes. The protein regulates a number of genes that play important roles in promoting oncogenesis, such as c-fos, cyclins A1 and cyclin D1 [19,20].
Quantitative proteomics using tandem mass spectrometry (MS) with stable isotope labeling is an important technology for measuring protein levels in a global fashion ([21]. Disease and control samples can be labeled with 'heavy' or 'light' isotopes and then measured by MS. The intensity ratios of the peptide peaks (or reporter ion peaks) in a given mass spectrum represent relative abundance of the proteins. TMT (tandem mass tag) and iTRAQ iIsobaric tag for relation and absolute quantitation) are isobaric chemical tags that enable concurrent identification and quantitation of proteins in different samples using tandem MS. The isobaric tags can be cleaved during collision-induced dissociation (CID) to yield an isotope series (reporter ions) representing the quantity of a single peptide of known mass from multiple samples. Since the peptide remains attached to the isobaric tags until CID is conducted, the peptide is simultaneously fragmented for sequence identification [22,23].

In this study, we have enriched and isolated oral CSC-like cells from a highly invasive UM1 oral cancer cell line and characterized the expression of stem cell markers in these cells. By using TMT labeling and liquid chromatography with tandem mass spectrometry (LC-MS/MS), we have performed a comparative proteomic analysis of CSC-like and non-CSC UM1 cells. Transcription co-activator CBP was found to be overexpressed whereas CREB-1 was significantly phosphorylated in CSC-like cells. Our findings suggest that the CREB-1 pathway is activated in the CSC-like UM1 cells and may play an important role in maintaining the stemness of oral CSC-like cells.

\section{Methods}

\section{Cell culture}

UM1 and UM2 cell lines were cultured in (D)MEM with $10 \%$ fetal bovine serum and 1\% penicillin/streptomycin (Invitrogen, Carlsbad, CA, USA) and maintained at $37^{\circ} \mathrm{C}$ in a humidified atmosphere of $5 \% \mathrm{CO}_{2}$. When the cancer cells reached confluence of approximately $90 \%$, the culture medium was changed to serum-free medium ((D)MEM) containing $1 \%$ penicillin/streptomycin and growth factors bFGF $(10 \mathrm{ng} / \mathrm{ml})$ and EGF $(10 \mathrm{ng} / \mathrm{ml})$ (Geminni Bio, Sacramento, CA, USA). The spherogenic and non-spherogenic UM1 cancer cells were harvested using trypsinization.

\section{Western blotting}

Following separation on a NuPAGENovex $4 \%$ to $12 \%$ Bis-Tris gel (Invitrogen) at $100 \mathrm{~V}$, the proteins were transferred to a nitrocellulose membrane (Bio-Rad, Hercules, CA, USA). Afterwards, the membranes were blocked for one hour in 5\% milk and then incubated with the following primary antibodies: rabbit polyclonal antibodies anti-CD44, anti-transketolase, anti-SOX-9, anti-CREB-1 and anti- 
phosphorylated CREB-1 (Santa Cruz Biotechnologies, Santa Cruz, CA, USA), rabbit polyclonal antibodies anti-SOX-2 and anti-hypoxia inducible factor $1 \propto$ (Gene Tex, Irvine, CA, USA), goat polyclonal antibody anti-OCT-3/4 and mouse monoclonal antibody anti-phosphoglycerate kinase 1 (Santa Cruz Biotechnologies). Blots were then washed with TBST (Tris-Buffered Saline with Tween 20) (1x), incubated with secondary antibody (Amersham, Piscataway, NJ, USA), and finally developed with the ECL plus detection kit (GE healthcare, Pittsburg, PA, USA).

\section{Tandem mass tagging}

Quantitative proteomic analysis was performed using TMT labeling (TMT-6plex, Thermo Fisher, Waltham, MA, USA) and two-dimensional LC-MS/MS. CSC-like and non-CSC cells were lysed on ice with a POLYTRON homogenizer (Kenematika, Bohemia, NY, USA) in $8 \mathrm{M}$ urea containing protease inhibitor cocktail (Calbiochem, San Diego, CA, USA). Equal amounts of proteins $(100 \mu \mathrm{g})$ from either CSClike or non-CSC UM1 cells were reduced with dithiothreitol, alkylated with iodoacetamide and digested with trypsin overnight. The resulting peptides were then labeled with TMT-126 (CSC-like) and TMT-127 (non-CSC) according to the manufacturer's protocol. Afterwards, we combined the labeled samples and fractionated the combined sample with a strong-cation exchange spin column (VIVAPURE S mini H, Sartorius Stedim, Bohemia, NY, USA). The initial filtrate and eight elutions under different concentrations of sodium acetate $(2.5 \mathrm{mM}, 5 \mathrm{mM}, 10 \mathrm{mM}, 20 \mathrm{mM}, 50 \mathrm{mM}$, $100 \mathrm{mM}, 250 \mathrm{mM}$ and $1 \mathrm{M}$ ) were collected, vacuum-dried and re-suspended in $0.1 \%$ formic acid for LC-MS/MS analysis.

\section{Liquid chromatography with tandem mass spectroscopy}

Fractionated peptide samples were loaded on an Agilent nano-trap column (Santa Clara, CA, USA) and washed for 10 minutes at $6 \mathrm{uL} /$ minute. Chromatography was performed using Eksigent two-dimensional-LC nanoflow system operating at $400 \mathrm{~nL} /$ minute and a 90-minute gradient. Separation was performed on a Microm $100 \times 0.1 \mathrm{~mm}$ C18AQ column $\left(200 \mathrm{~A}^{\circ}, 3 \mu \mathrm{m}\right)$ using solvent A ( $0.1 \%$ formic acid) and solvent $\mathrm{B}$ (99.9\% ACN, 0.1\% formic acid) over a 90-minute gradient: $0 \%$ to $30 \%$ B (60 minutes), $35 \%$ to $80 \%$ B (10 minutes), $80 \%$ $\mathrm{B}$ (5 minutes), and then the column was re-equilibrated. Data-dependent LC-MS-MS was performed using an Orbitrap LTQ XL mass spectrometer (Thermo Fisher, San Jose, CA, USA) with the MS scan performed in the Orbitrap analyzer using two microscans of maximum time $50 \mathrm{~ms}$ and an automatic gain control of 1E5. The top five ions of intensity greater than 5,000 (excluding single charge states) were selected for MS/MS. In each cycle, a MS-MS fragmentation was generated using subsequent CID (collision energy 35) and HCD (Higher energy collision dissociation) (collision energy 42) scans performed in the LTQ Iontrap and
Orbitrap cell, respectively, which were then combined in data processing to obtain quantitative and qualitative data.

\section{Data analysis}

Database searching was performed using the Proteome Discoverer 1.2 (Thermo Fisher Scientific) against the International Proteome Index (IPI) database (IPI.HUMAN. v3.16, 62322 entries). A workflow was created for the purpose of analysis of LC-MS/MS raw data. First, the raw data files were loaded into the Spectrum Files. The parameters in the Spectrum Selector were set up as default, and TMT 6-plex (TMT-126 and TMT-127) was chosen in Reporter Ion Quantifier. SEQUEST algorithm was used for data searching to identify proteins. The parameters for SEQUEST database searching were as follows: missed cleavage of two; the dynamic modifications were oxidation $(+15.995 \mathrm{Da})(\mathrm{M})$, deamidation $(+0.984 \mathrm{Da})(\mathrm{N})$ and phosphorylation $(+79.9966 \mathrm{Da})(\mathrm{S}, \mathrm{T}, \mathrm{Y})$. The static modifications were TMT-6plex (+229.163 Da) (any N-terminus and $\mathrm{K})$ and Carbamidomethyl (+57 Da) (C). The false discovery rate was below $1 \%$ for protein identification. For protein quantitation, 'Normalize on Protein Median' was used for normalization and proteins with a fold change of 1.2 were generally considered as differentially expressed. The gene ontology (GO) and pathway analyses were performed using the DAVID bioinformatics resource [24].

\section{Results}

\section{Enrichment and isolation of CSC-like cells}

To enrich and isolate CSC-like cells, both UM1 and UM2 cancer cells were maintained in serum-free media containing growth factors bFGF and EGF. After three weeks, a subset of UM1 cells started to form spherogenic aggregates, as shown in Figure 1. Significant formation of spheres was observed in the UM1 cells during the fourth week. So far, we have obtained spherogenic CSC-like cells from all 18 plates $(10 \mathrm{~cm})$ of UM1 cells cultured under serum-free medium (100\% successful rate). In contrast, UM2 cells were not spherogenic at all in serum-free medium and lysed rapidly after three weeks. To isolate the spherogenic UM1 cells, the cultures were carefully treated with trypsin in the fifth week. The sphere-like cellular aggregates became detached from the adherent layer of cancer cells and were harvested. Afterwards, the adherent cells were collected with continuous trypsinization. The cells present in the sphere-like aggregates are considered as CSC-like cancer cells whereas the bottom layer of adherent cells are considered as non-CSC cancer cells. Both types of cells were then lysed in $8 \mathrm{M}$ urea with a homogenizer for subsequent analysis of stem cell markers and quantitative proteomics. CSC-like UM1 cells were spherogenic cellular aggregates from all the twenty-one culture dishes. 

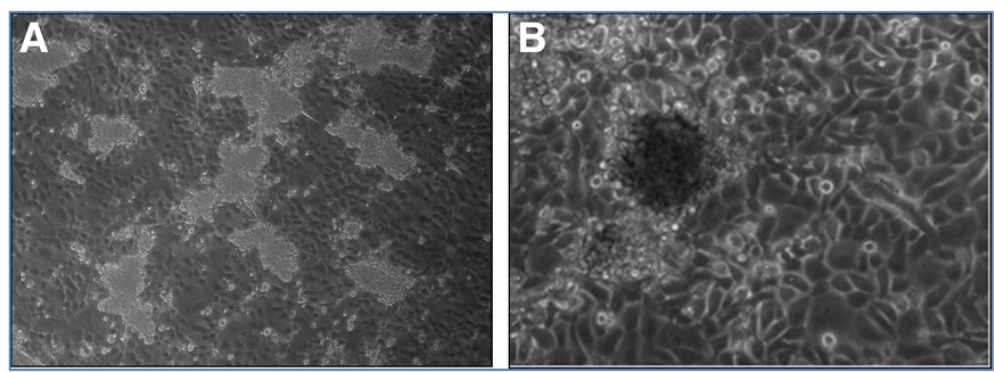

Figure 1 A subset of UM1 oral cancer cells were spherogenic when cultured in serum-free medium containing growth factors bFGF and EGF for three to four weeks (A). A close-up of the spherogenic cancer cells is shown in (B). bFGF, basic fibroblast growth factor; EGF, epidermal growth factor.

Expression of stem cell marker proteins in CSC-like cells To characterize the CSC-like cells (cells present in the sphere-like aggregates), we compared the expression levels of CD44, OCT-4, SOX2 and SOX9 between CSClike (spherogenic) and non-CSC (non-spherogenic) UM1 cancer cells with Western blotting. All the stem cell markers were significantly up-regulated in CSC-like UM1 cells when compared to non-CSC UM1 cells (Figure 2).

\section{Expression of HIF-1a and PGK-1 in CSC-like cells}

We also compared the expression levels of hypoxiainducible factor HIF- $1 \alpha$ and two metabolic enzymes, transketolase (TKT) and phosphoglycerate kinase 1 (PGK-1), between CSC-like and non-CSC UM1 cells (Figure 2) with Western blotting. TKT was not significantly different between the two cell phenotypes. However, both HIF- $1 \alpha$ and PGK1 were down-regulated in CSC-like cells versus non-CSC cells.

\section{Quantitative proteomic analysis of CSC-like UM1 cancer cells}

Using TMT labeling and two-dimensional LC-MS/MS, we performed a comparative proteomic analysis of CSClike and non-CSC UM1 cells. The database search with the Proteome Discoverer indicated that 4,397 proteins had at least one tryptic peptide matched with high confidence and 936 peptides (21\%) were labeled with TMT (Additional file 1: Table S1). There were 1,026 proteins with two tryptic peptides matched with high confidence, including 425 with two TMT-labeled peptides (Figure 3). Many proteins on cell cycle, metabolism, small G protein signal transduction, translational elongation, development, and RNA splicing pathways were found to be differentially expressed ( $>1.2$ fold) between the CSC-like and non-CSC UM1 cells (Figure 4, Tables 1, 2, 3 and 4).

\section{CREB pathway is activated in CSC-like UM1 cancer cells} Quantitative proteomic analysis revealed that CBP was over-expressed in CSC-like cells when compared to non-
CSC UM1 cells. This was confirmed by Western blot analysis, as shown in Figure 5. Intriguingly, although no significant difference in the total expression level of CREB-1 was observed between non-CSC and CSC-like cells, the expression level of phosphorylated CREB-1
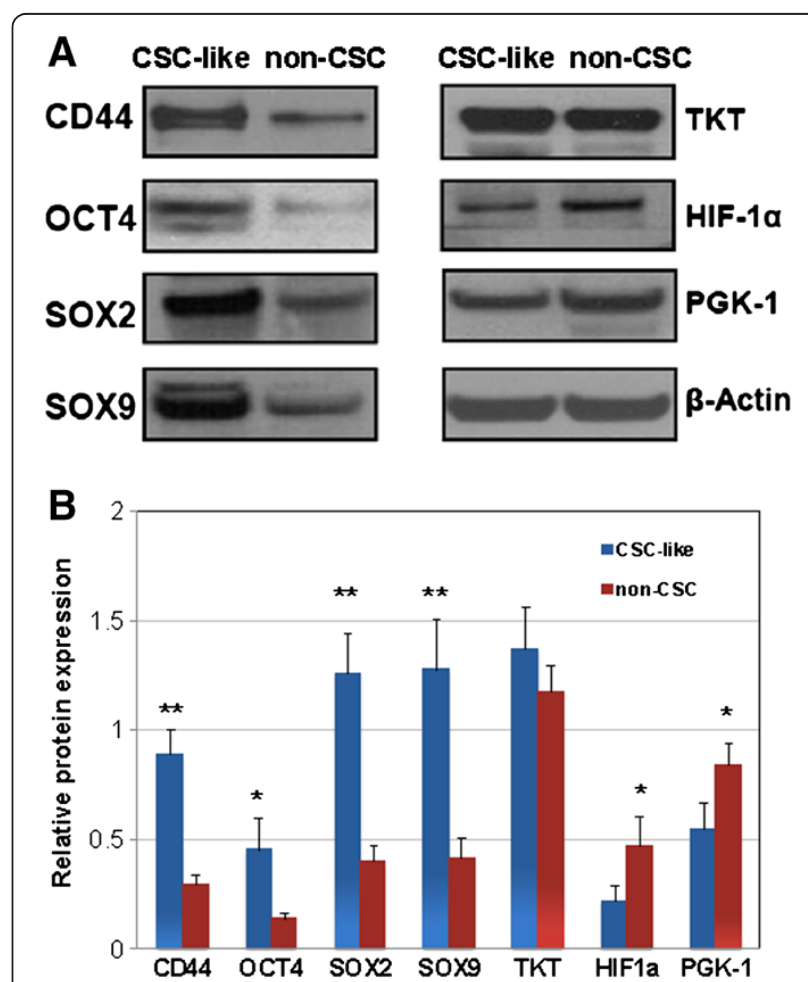

Figure 2 Western blot analysis of CD44, octamer-binding transcription factor 4 (OCT4), sex determining region Y-box 2 (SOX2), SOX9, transketolase (TKT), hypoxia-inducible factor 1 alpha (HIF-a) and phosphoglycerate kinase 1 (PGK-1) in CSC-like and non-CSC UM1 cells (A). The normalized levels of all seven proteins are shown in (B). Stem cell markers CD44, OCT4, SOX2 and SOX9 were up-regulated in CSC-like UM1 cells whereas HIF-a and PGK-1 were down-regulated in CSC-like cells when compared to non-CSC UM1 cells $(n=3)$. No significant difference in expression was observed for TKT. ${ }^{*}, P<0.05 ;{ }^{*}, P<0.01$. CSC, cancer stem cells. 

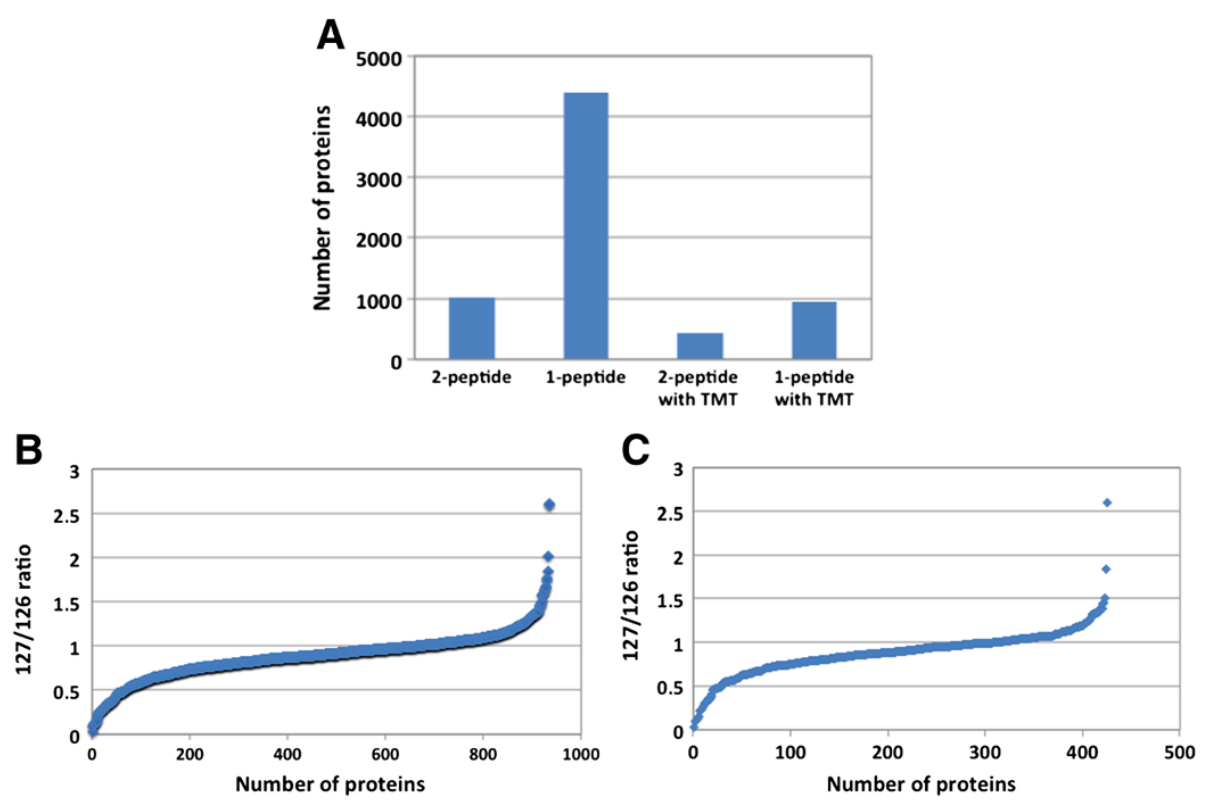

Figure 3 Quantitative proteomic analysis of CSC-like and non-CSC UM1 cancer cells using tandem mass tagging (TMT) and two-dimensional LC-MS/MS. Ratios of 127 to 126 represent the relative levels of proteins between non-CSC (TMT-127) and CSC-like (TMT-126) UM1 cells. (A) depicts the corresponding number of protein IDs with $\geq 1$ matched peptide $(n=4,397), \geq 2$ matched peptides $(n=1,026), \geq 1$ matched and TMT-labeled peptide $(n=936)$, or $\geq 2$ matched and TMT-labeled peptides $(n=425)$. (B) illustrates the TMT-127/TMT-126 ratios for 936 proteins with $\geq 1$ matched and TMT-labeled peptide. (C) illustrates the TMT-127/TMT-126 ratios for 425 proteins with $\geq 2$ matched and TMT-labeled peptides. CSC, cancer stem cells; LC-MS/MS, liquid chromatography-tandem mass spectroscopy.

(p-CREB-1) was significantly higher in CSC-like UM1 cells than in non-CSC UM1 cells.

\section{Discussion}

To enrich CSCs from oral cancer cell lines, we maintained UM1 and UM2 oral cancer cells in serum-free culture medium with bFGF and EGF. Both UM1 and UM2 cell lines were initially established from the same tongue cancer patient [25]. UM1 cells appeared to be highly invasive whereas UM2 cells were found to be lowly invasive. Our trans-well invasion assays indeed demonstrated that UM1 cancer cells were at least eightfold more invasive than UM2 cancer cells (data not shown). After being maintained in serum-free medium for three weeks, a subset of UM1 cells started to form spherelike cellular aggregates (CSC-like). It is well known that serum-free medium with selected growth factors is capable of maintaining cancer cells in the undifferentiated state. In fact, CSC-like cells enriched with serum-free medium containing bFGF and EGF mirror the phenotype and genotype of primary tumors more closely than do cancer cell lines cultured in complete serum medium [26]. Our experiment agreed with these previous studies and further confirmed that oral CSC-like cells can be enriched with sphere-formation assay under serum-free culture conditions $[13,17]$. In contrast, the UM2 tongue cancer cells were not spherogenic and eventually lysed after three weeks of culture in serum-free medium. UM1 and UM2 cell lines were derived from the same patient's tongue squamous cell carcinoma. Our studies suggest that a CSClike subpopulation is only present in highly invasive UM1 cancer cells but absent in the lowly invasive UM2 cancer cells.

To confirm that the spherogenic UM1 cells are CSClike, we compared the expression levels of stem cell markers, including CD44, OCT4, SOX2 and SOX9, between the isolated spherogenic and non-spherogenic UM1 cells. All these markers were found to be significantly up-regulated in spherogenic cells (Figure 2). CD44 is a CSC marker known to be involved in cancer cell adhesion and migration. The expression of CD44 has been correlated with tumor progression and poor diagnosis in oral/head and neck cancer. Prince et al. purified CSC-like cells from HNSCC by selecting the CD44+ cells $[15,16]$. The CD44+ cells were found to be tumorigenic and differentially expressed the stem cell marker gene BMI1, at both the RNA and protein levels. In the study by Chiou et al., CD44 was found to be down-regulated whereas CD133 was over-expressed in their enriched CSC-like cells. As the authors pointed out, this may be due to the fact that the serum-free cultivation mainly enriched the $\mathrm{CD} 133^{+}$ CSCs [17].

OCT4 and SOX2 are frequently used as markers for undifferentiated cells. OCT-4 is critically involved in the self-renewal of undifferentiated embryonic stem cells as evidenced by the fact that gene knockdown of OCT4 


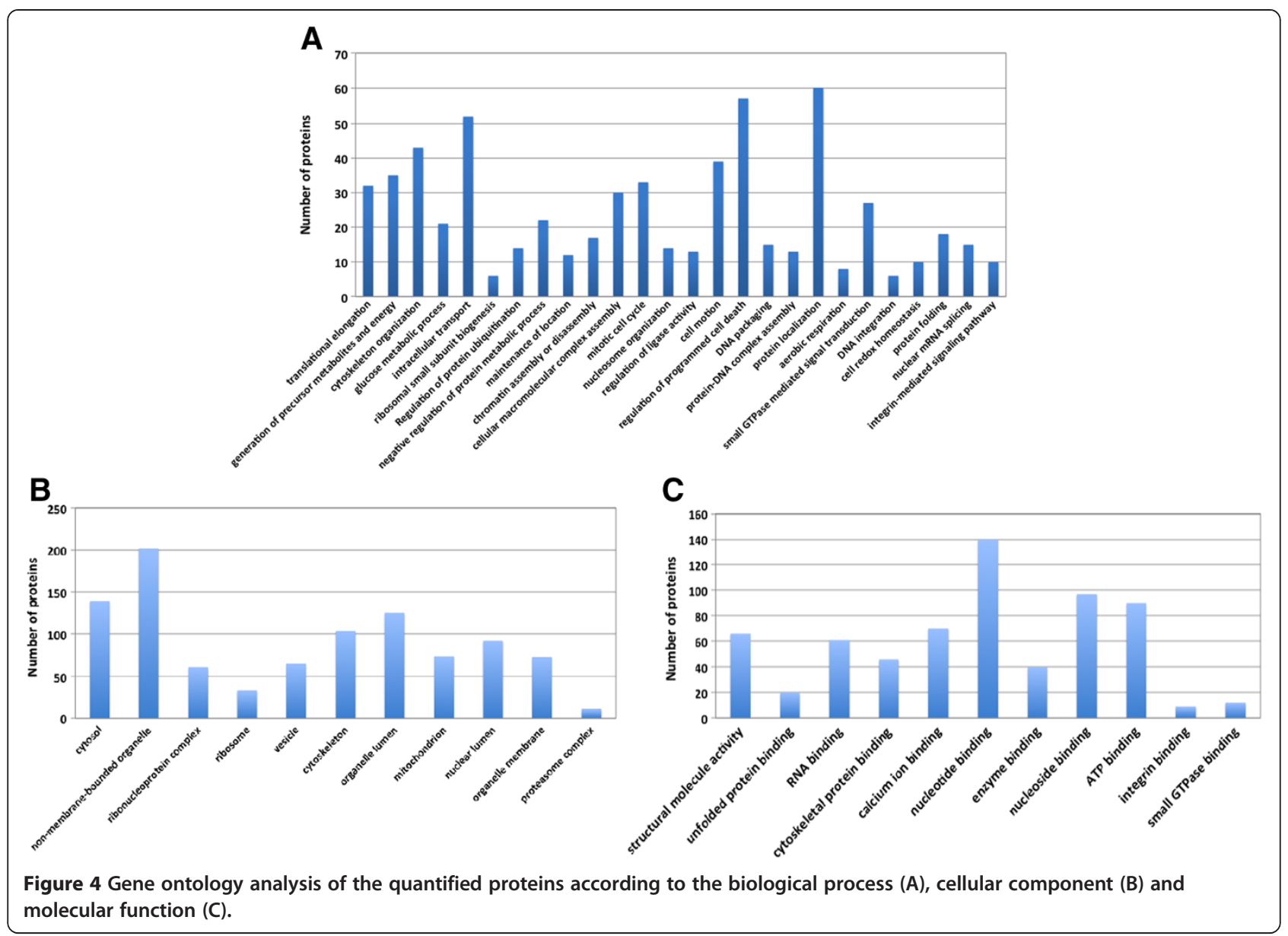

promotes differentiation in human embryonic stem cells [27]. Previous studies also indicated that higher OCT4 expression correlates with oral cancer progression and metastasis, as well as contributes to oral cancer patient mortality. It is speculated that deregulation of Oct-4 gene may perturb the normal differentiation program and predispose to tumor formation [28]. SOX2 is a member of the Sox family of transcription factors, which serves as a key regulator of stem cell pluripotency and differentiation. The LIF (leukemia inhibitory factor) signaling pathway, which maintains pluripotency in mouse embryonic stem cells, activates SOX2 downstream of the JAK-STAT signaling pathway and Nanog downstream of PI3K-AKT, respectively, and maintains the expression of OCT4 [29]. As a feedback mechanism, both OCT4 and SOX2 positively regulate the transcription of pluripotency circuitry proteins in the LIF signaling pathway. In fact, SOX2 is up-regulated in lung squamous cell carcinoma, and activates cellular migration and anchorageindependent growth [30]. Similar to SOX2, SOX9 plays a pivotal role in many stages of mammalian development, with its levels strictly controlled for normal embryogenesis. The expression of SOX9 is up-regulated in a variety of human cancers, which correlates with tumor malignancy and progression. In particular, SOX9 promotes proliferation and prevents differentiation in intestinal stem cell/progenitors, acting downstream of Wnt signaling [31]. Overall, the significant over-expression of stem cell markers SOX2, OCT4, SOX9 and CD44 suggests that the cells present in spherical aggregates are CSC-like whereas the non-spherogenic, adherent layer of cells are non-CSC cancer cells.

We also compared the expression of HIF-1 $\alpha$ and two metabolic enzymes PGK1 and TKT between CSC-like and non-CSC cells. TKT, a critical metabolic enzyme of the pentose phosphate pathway, was not significantly different between the two cell types. However, both HIF- $1 \alpha$ and PGK1 were found to be down-regulated in CSC-like cancer cells compared to non-CSC cancer cells. HIF-1 is a heterodimeric transcription factor that consists of two subunits, the HIF- $1 \beta$ subunit which is constitutively expressed and the HIF- $1 \alpha$ subunit which is regulated by oxygen levels. The protein plays an important role in cancer cell metabolism by activating the genes for glucose transporters and glycolytic enzymes resulting in an increased glycolytic rate [32]. PGK1 is an ATP-generating enzyme in the glycolytic 
Table 1 A list of differentially expressed proteins regulating transcription or translation

\begin{tabular}{|c|c|c|c|c|c|c|}
\hline Accession & \# Peptides & MW [kDa] & Calc. pl & 127/126 non-CSC:CSC & $\mathrm{SD}_{127 / 126}$ & Protein description \\
\hline IPI:IPI00410017.1 & 2 & 61.1 & 9.07 & 2.592 & 1.429 & Poly(A)-binding protein 1 \\
\hline IPI:IPI00375141.1 & 5 & 412.1 & 5.83 & 1.456 & 0.421 & Dystrophin \\
\hline IPI:IPI00009771.5 & 2 & 69.9 & 5.59 & 1.440 & 0.451 & Lamin-B2 \\
\hline IPI:IPI00291783.3 & 3 & 168.5 & 6.60 & 1.337 & 0.164 & Gem-associated protein 5 \\
\hline IPI:IPI00183085.2 & 2 & 35.2 & 6.34 & 1.282 & 0.112 & Highly similar to $\mathrm{N}$-myc downstream regulated 1 \\
\hline IPI:IPI00179700.3 & 3 & 11.7 & 10.32 & 1.227 & 0.179 & High mobility group protein HMG-I/HMG-Y \\
\hline IPI:IPI00651769.1 & 2 & 126.6 & 5.63 & 0.832 & 0.140 & Myelin transcription factor 1-like protein \\
\hline IPI:IPI00465070.6 & 8 & 15.3 & 11.12 & 0.812 & 0.169 & Histone H3.1 \\
\hline IPI:IPI00141938.3 & 5 & 12.1 & 10.46 & 0.801 & 0.070 & $\mathrm{H} 2 \mathrm{~A}$ histone family, member $\mathrm{V}$ isoform 2 \\
\hline IPI:IPI00328737.1 & 2 & 98.6 & 8.40 & 0.794 & 0.110 & Zinc finger protein 598 \\
\hline IPI:IPI00006196.2 & 3 & 236.4 & 5.80 & 0.792 & 0.073 & $\begin{array}{l}\text { Nuclear mitotic apparatus protein 1, asymmetric } \\
\text { division related }\end{array}$ \\
\hline IPI:IPI00027252.6 & 4 & 33.3 & 9.83 & 0.789 & 0.109 & Prohibitin-2, mediator of transcriptional repression \\
\hline IPI:IPI00745230.1 & 2 & 343.9 & 8.47 & 0.788 & 0.008 & REV3-like, catalytic subunit of DNA polymerase zeta \\
\hline IPI:IPI00000897.1 & 2 & 218.8 & 7.37 & 0.779 & 0.148 & Probable helicase with zinc-finger domain \\
\hline IPI:IPI00220834.7 & 3 & 82.5 & 5.81 & 0.773 & 0.195 & ATP-dependent DNA helicase 2 subunit 2 \\
\hline IPI:IPI00386211.3 & 3 & 330.3 & 5.08 & 0.760 & 0.301 & 1 \\
\hline IPI:IPI00027107.5 & 5 & 49.8 & 7.61 & 0.760 & 0.136 & Tu translation elongation factor, mitochondrial \\
\hline IPI:IPI00021405.3 & 26 & 74.1 & 7.02 & 0.755 & 0.170 & Isoform A of Lamin-A/C \\
\hline IPI:IPI00020153.2 & 2 & 416.1 & 7.55 & 0.749 & 0.122 & Zinc finger protein 231 \\
\hline IPI:IPI00219038.8 & 7 & 15.2 & 11.27 & 0.718 & 0.161 & Histone H3.3 \\
\hline IPI:IPI00166612.9 & 2 & 448.9 & 4.78 & 0.711 & 0.063 & Cardiomyopathy associated 5 protein \\
\hline IPI:IPI00337766.5 & 3 & 91.7 & 7.39 & 0.705 & 0.215 & Zinc finger, $\mathrm{CCHC}$ domain containing 2 \\
\hline IPI:IPI00642900.2 & 3 & 241.1 & 7.05 & 0.697 & 0.147 & $\begin{array}{l}\text { Transcription repressor CCR4-NOT transcription } \\
\text { complex subunit } 1\end{array}$ \\
\hline IPI:IPI00401829.3 & 2 & 93.6 & 6.71 & 0.645 & 0.231 & Coiled-coil domain-containing protein 175 \\
\hline IPI:IPI00216457.6 & 6 & 14.0 & 10.90 & 0.628 & 0.093 & Histone $\mathrm{H} 2 \mathrm{~A}$ type $2-\mathrm{A}$ \\
\hline IPI:IPI00065310.2 & 3 & 75.3 & 5.68 & 0.626 & 0.266 & Coiled-coil domain-containing protein 27 \\
\hline IPI:IPI00014213.1 & 2 & 101.9 & 8.22 & 0.617 & 0.295 & Probable leucyl-tRNA synthetase, mitochondrial precursor \\
\hline IPI:IPI00294575.7 & 2 & 91.8 & 7.02 & 0.577 & 0.628 & Cell division cycle protein 27 homolog \\
\hline IPI:IPI00020991.2 & 2 & 61.1 & 9.01 & 0.568 & 0.122 & CDKN2A interacting protein \\
\hline IPI:IPI00171611.5 & 8 & 15.4 & 11.27 & 0.563 & 0.177 & H3 histone family, member $\mathrm{M}$ \\
\hline IPI:IPI00007928.4 & 2 & 273.4 & 8.84 & 0.550 & 0.196 & Pre-mRNA-processing-splicing factor 8 \\
\hline IPI:IPI00021520.1 & 2 & 37.2 & 9.11 & 0.478 & 0.100 & Glucocorticoid receptor AF-1 coactivator-1 \\
\hline IPI:IPI00619932.4 & 2 & 265.2 & 8.53 & 0.382 & 0.047 & CREB-binding protein \\
\hline IPI:IPI00024163.1 & 2 & 155.6 & 8.48 & 0.303 & 0.367 & DNA-directed RNA polymerase III largest subunit \\
\hline IPI:IPI00387050.3 & 2 & 55.5 & 9.57 & 0.216 & 0.349 & BUD13 homolog, splicing factor \\
\hline IPI:IPI00015557.3 & 2 & 17.7 & 6.01 & 0.097 & 0.248 & Coiled-coil domain-containing protein 48 \\
\hline
\end{tabular}

CSC, cancer stem cells; MW, molecular weight.

pathway regulated by HIF-1 $\alpha$. Recent studies suggest that prostate cancer cell-derived PGK-1 induces osteoblastic differentiation of bone marrow stromal cells, affecting bone formation at the metastatic site. PGK-1 may also induce the differentiation of gastric cancer stem cells [33,34]. Since HIF-1 $\alpha$ positively regulates glycolytic enzymes, including
PGK1, it is not surprising that PGK-1 was down-regulated, the same as HIF-1 $\alpha$, in CSC-like UM1 cells.

Functional analysis of the differentially expressed proteins using DAVID revealed multiple pathways significantly associated with CSCs, such as ribosome, cell cycle, development, glycolysis, translation elongation, 
Table 2 A list of quantified enzymes including metabolic enzymes between CSC-like and non-CSC UM1 cells

\begin{tabular}{|c|c|c|c|c|c|c|}
\hline Accession & \# Peptides & MW [kDa] & Calc. pl & 127/126 non-CSC:CSC & $\mathrm{SD}_{127 / 126}$ & Protein description \\
\hline IPI:IPI00219568.3 & 5 & 44.6 & 8.54 & 1.389 & 0.190 & Phosphoglycerate kinase, testis specific (PGK2) \\
\hline IPI:IPI00289800.7 & 2 & 59.2 & 6.84 & 1.339 & 0.014 & Glucose-6-phosphate dehydrogenase \\
\hline IPI:IPI00005705.1 & 2 & 37.0 & 6.54 & 1.258 & 0.161 & $\begin{array}{l}\text { Serine/threonine-protein phosphatase 1, catalytic } \\
\text { subunit, gamma isozyme }\end{array}$ \\
\hline IPI:IPI00218353.3 & 3 & 121.0 & 7.75 & 1.210 & 0.287 & Probable cation-transporting ATPase 13A1 \\
\hline IPI:IPI00007188.4 & 7 & 32.7 & 9.74 & 0.866 & 0.085 & ADP/ATP translocase 2 \\
\hline IPI:IPI00027442.3 & 2 & 106.7 & 5.49 & 0.861 & 0.226 & Alanyl-tRNA synthetase \\
\hline IPI:IPI00440493.2 & 9 & 59.7 & 9.13 & 0.824 & 0.161 & ATP synthase alpha chain, mitochondrial precursor \\
\hline IPI:IPI00029144.1 & 2 & 130.2 & 5.21 & 0.818 & 0.055 & $\begin{array}{l}\text { Serine/threonine-protein phosphatase 2A 72/130 kDa } \\
\text { regulatory subunit B }\end{array}$ \\
\hline IPI:IPI00014375.1 & 2 & 109.2 & 5.50 & 0.790 & 0.164 & Glutamyl aminopeptidase \\
\hline IPI:IPI00513928.1 & 2 & 33.0 & 8.15 & 0.768 & 0.076 & Acyl-coenzyme A thioesterase 2 \\
\hline IPI:IPI00018206.3 & 3 & 47.4 & 9.01 & 0.734 & 0.141 & Aspartate aminotransferase, mitochondrial precursor \\
\hline IPI:IPI00291006.1 & 8 & 35.5 & 8.68 & 0.732 & 0.194 & Malate dehydrogenase, mitochondrial precursor \\
\hline IPI:IPI00297084.7 & 2 & 50.8 & 6.55 & 0.731 & 0.011 & $\begin{array}{l}\text { Dolichyl-diphosphooligosaccharide-protein } \\
\text { glycosyltransferase }\end{array}$ \\
\hline IPI:IPI00303476.1 & 15 & 56.5 & 5.40 & 0.730 & 0.203 & ATP synthase beta chain, mitochondrial precursor \\
\hline IPI:IPI00022774.2 & 4 & 89.1 & 5.26 & 0.665 & 0.078 & Transitional endoplasmic reticulum ATPase \\
\hline IPI:IPI00438875.2 & 2 & 98.0 & 7.34 & 0.658 & 0.281 & $\begin{array}{l}\text { Channel kinase } 2 \text { (Isoform M6-kinase } 2 \text { of Transient } \\
\text { receptor potential cation channel subfamily M } \\
\text { member 6) }\end{array}$ \\
\hline IPI:IPI00640240.1 & 2 & 58.6 & 9.13 & 0.648 & 0.149 & $\begin{array}{l}\text { Serine palmitoyltransferase, long chain base } \\
\text { subunit 2-like }\end{array}$ \\
\hline IPI:IPI00646947.1 & 3 & 95.1 & 5.77 & 0.626 & 0.222 & $\begin{array}{l}\text { Highly similar to Sarcoplasmic/endoplasmic } \\
\text { reticulum calcium ATPase } 1\end{array}$ \\
\hline IPI:IPI00009634.1 & 4 & 49.9 & 9.11 & 0.546 & 0.198 & $\begin{array}{l}\text { Sulfide:quinone oxidoreductase, mitochondrial } \\
\text { precursor }\end{array}$ \\
\hline IPI:IPI00657779.1 & 2 & 16.5 & 9.58 & 0.492 & 0.172 & Peptidylprolyl isomerase F \\
\hline IPI:IPI00552972.2 & 3 & 56.3 & 6.33 & 0.473 & 0.208 & $\begin{array}{l}\text { Dolichyl-diphosphooligosaccharide-protein } \\
\text { glycosyltransferase subunit } 2\end{array}$ \\
\hline IPI:IPI00658151.1 & 3 & 354.1 & 8.51 & 0.465 & 0.276 & Striated muscle preferentially expressed protein kinase \\
\hline IPI:IPI00022314.1 & 5 & 24.7 & 8.25 & 0.400 & 0.263 & Superoxide dismutase [Mn], mitochondrial precursor \\
\hline IPI:IPI00007611.1 & 3 & 23.3 & 9.96 & 0.353 & 0.267 & ATP synthase,subunit $O$, mitochondrial precursor \\
\hline
\end{tabular}

CSC, cancer stem cells; MW, molecular weight.

proteasome, small $G$ protein signal transduction and RNA splicing. GO analysis of the quantified proteins showed similar functional categories as the pathway analysis (Figure 4). A number of the differentially expressed proteins are transcription factors/activators/ suppressors, translation elongation factors, or spicing factors (Table 1). For instance, both prohibitin-2 (PHB2) and lamin A were found to be up-regulated whereas Lamin-B2 was down-regulated in CSC-like UM1 cells. PHB2 acts as a mediator of transcriptional repression by nuclear hormone receptors via recruitment of histone deacetylases. Recent studies have demonstrated that epidermal stem cells are highly dependent on PHB2 for maintaining mitochondrial function [35]. Nuclear lamins are fibrous proteins which interact with membrane-associated proteins to form the nuclear lamina on the interior of the nuclear envelope. They are involved in transcriptional regulation, breakdown and reformation of the nuclear envelope during mitosis, as well as the positioning of nuclear pores. In fact, colorectal cancer patients expressing lamin $\mathrm{A} / \mathrm{C}$ in their tumor tissue were found to have a higher risk of mortality compared to patients with lamin $\mathrm{A} / \mathrm{C}$-negative tumors. The poor outcome associated with lamin A/C-positive tumors might be reflective of a more stem-cell-like phenotype $[36,37]$.

The proteomic analysis suggests that metabolic pathways may be different between the CSC-like and non-CSC 
Table 3 A list of quantified proteins related to $\mathbf{G}$ protein signal transduction

\begin{tabular}{|c|c|c|c|c|c|c|}
\hline Accession & \# Peptides & $\mathrm{MW}[\mathrm{kDa}]$ & Calc. pl & 127/126 non-CSC:CSC & $\mathrm{SD}_{127 / 126}$ & Protein description \\
\hline IPI:IPI00009342.1 & 9 & 189.1 & 6.48 & 0.938 & 0.206 & Ras GTPase-activating-like protein IQGAP1 \\
\hline IPI:IPI00183572.3 & 3 & 174.0 & 7.02 & 0.884 & 0.415 & $\begin{array}{l}\text { Dedicator of cytokinesis protein } 7 \text {, guanine } \\
\text { nucleotide exchange factor }\end{array}$ \\
\hline IPI:IPI00383449.2 & 3 & 23.5 & 9.95 & 0.884 & 0.115 & Ras-related protein Rab-15 \\
\hline IPI:IPI00337802.3 & 3 & 100.9 & 7.71 & 0.867 & 0.273 & Disheveled-associated activator of morphogenesis 1 \\
\hline IPI:IPI00015148.3 & 2 & 20.8 & 5.78 & 0.852 & 0.051 & Ras-related protein Rap-1b \\
\hline IPI:IPI00016342.1 & 4 & 23.5 & 6.70 & 0.848 & 0.143 & Ras-related protein Rab-7 \\
\hline IPI:IPI00746773.1 & 2 & 179.4 & 7.66 & 0.804 & 0.100 & IQ motif containing GTPase activating protein 3 \\
\hline IPI:IPI00216989.5 & 3 & 82.4 & 7.69 & 0.740 & 0.125 & G protein-regulated inducer of neurite outgrowth 3 \\
\hline IPI:IPI00008964.3 & 4 & 22.2 & 5.73 & 0.733 & 0.164 & Ras-related protein Rab-1B \\
\hline IPI:IPI00016513.5 & 3 & 22.5 & 8.38 & 0.727 & 0.120 & Ras-related protein Rab-10 \\
\hline IPI:IPI00607850.1 & 2 & 176.9 & 6.58 & 0.654 & 0.072 & Citron Rho-interacting kinase \\
\hline IPI:IPI00168769.6 & 3 & 222.4 & 7.81 & 0.647 & 0.244 & Exophilin 5 (Rab GTPase binding protein) \\
\hline IPI:IPI00455852.1 & 4 & 91.9 & 8.25 & 0.642 & 0.234 & Rho guanine nucleotide exchange factor 15 \\
\hline IPI:IPI00022479.4 & 3 & 531.9 & 6.04 & 0.554 & 0.264 & Guanine nucleotide exchange factor p532 \\
\hline
\end{tabular}

CSC, cancer stem cells; MW, molecular weight.

Table $4 \mathrm{~A}$ list of differentially expressed proteins related to development or differentiation

\begin{tabular}{|c|c|c|c|c|c|c|}
\hline Accession & \# Peptides & MW [kDa] & Calc. pl & 127/126 non-CSC:CSC & $\mathrm{SD}_{127 / 126}$ & Protein description \\
\hline IPI:IPI00031547.1 & 3 & 107.4 & 5.00 & 0.146 & 0.158 & Desmoglein-3 precursor \\
\hline IPI:IPI00027462.1 & 6 & 13.2 & 6.13 & 0.297 & 0.224 & Protein S100-A9 \\
\hline IPI:IPI00746049.1 & 3 & 131.1 & 6.20 & 0.326 & 0.212 & Similar to Breast cancer antigen NY-BR-1.1 \\
\hline IPI:IPI00007047.1 & 2 & 10.8 & 7.03 & 0.351 & 0.186 & Protein S100-A8 \\
\hline IPI:IPI00619932.4 & 2 & 265.2 & 8.53 & 0.382 & 0.047 & CREB-binding protein \\
\hline IPI:IPI00027412.4 & 2 & 37.2 & 5.82 & 0.470 & 0.086 & $\begin{array}{l}\text { Carcinoembryonic antigen-related cell adhesion } \\
\text { molecule } 6\end{array}$ \\
\hline IPI:IPI00168698.1 & 2 & 128.5 & 6.09 & 0.470 & 0.136 & PDZ domain-containing protein 8 \\
\hline IPI:IPI00657779.1 & 2 & 16.5 & 9.58 & 0.492 & 0.172 & Peptidylprolyl isomerase $\mathrm{F}$ \\
\hline IPI:IPI00646867.1 & 4 & 49.6 & 5.25 & 0.555 & 0.142 & Vimentin \\
\hline IPI:IPI00168913.1 & 2 & 139.8 & 6.65 & 0.738 & 0.269 & $\begin{array}{l}\text { Limbin, positive regulator of the hedgehog } \\
\text { signaling pathway }\end{array}$ \\
\hline IPI:IPI00179700.3 & 3 & 11.7 & 10.32 & 1.227 & 0.179 & High mobility group protein HMG-1/HMG-Y \\
\hline IPI:IPI00021812.1 & 2 & 312.3 & 6.73 & 1.234 & 0.320 & Neuroblast differentiation-associated protein AHNAK \\
\hline IPI:IPI00183085.2 & 2 & 35.2 & 6.34 & 1.282 & 0.112 & Highly similar to $\mathrm{N}$-myc downstream regulated 1 \\
\hline IPI:IPI00410096.1 & 3 & 197.5 & 6.13 & 1.333 & 0.267 & Selective LIM binding factor homolog \\
\hline IPI:IPI00414203.2 & 3 & 81.4 & 5.97 & 1.351 & 0.265 & Predicted testis protein \\
\hline IPI:IPI00220709.3 & 9 & 33.0 & 4.67 & 1.386 & 0.160 & Isoform 2 of Tropomyosin beta chain \\
\hline IPI:IPI00220827.4 & 3 & 4.9 & 5.36 & 1.392 & 0.108 & Thymosin beta-10 \\
\hline IPI:IPI00009771.5 & 2 & 69.9 & 5.59 & 1.440 & 0.451 & Lamin-B2 \\
\hline IPI:IPI00375141.1 & 5 & 412.1 & 5.83 & 1.456 & 0.421 & $\begin{array}{l}\text { Dystrophin, morphogenesis and DNA-dependent } \\
\text { regulation of transcription }\end{array}$ \\
\hline IPI:IPI00005750.1 & 3 & 255.3 & 9.11 & 1.840 & 0.499 & $\begin{array}{l}\text { Polycystic kidney disease and receptor for egg } \\
\text { jelly-related protein }\end{array}$ \\
\hline
\end{tabular}




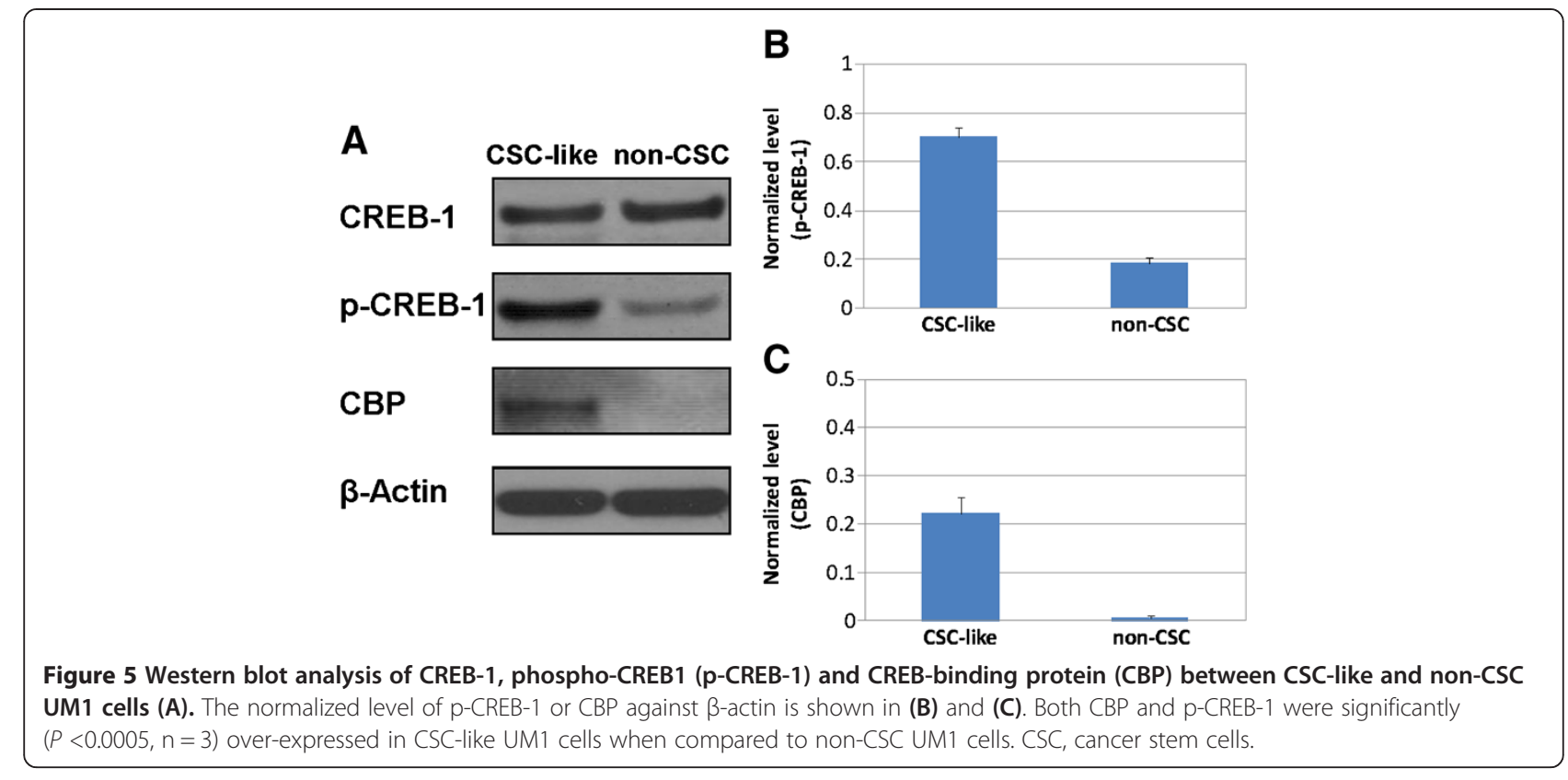

UM1 cells (Table 2 ). ATP synthase ( $\alpha-$, $\beta$-, and $\mathrm{O}$-subunits) was found to be over-expressed in CSC-like cells compared to non-CSC UM1 cells. ATP synthase is an important enzyme that provides cells with energy through the synthesis of ATP. Down-regulation of ATP synthase $\beta$-subunit expression was reported in liver, kidney, colon, squamous esophageal and lung carcinomas, as well as in breast and gastric adenocarcinomas, indicating that bioenergetic dysfunction of mitochondria is a hallmark of these types of cancers [38-40]. However, in our present study, mitochondrial ATP synthase was up-regulated in CSC-like UM1 cells, suggesting an increase of mitochondrial bioenergetic production in CSC-like cells when compared to non-CSC cells. This is in agreement with the observation of a compromised glycolysis as indicated by down-regulation of HIF- $1 \alpha$ and glycolytic enzyme PGK1 (Figure 2). Together these results seem to suggest that there is a shift from glycolytic to mitochondrial bioenergetic production in CSC-like cells when compared to non-CSC cells.

Our study also indicates that a group of small $G$ proteins were over-expressed in CSC-like cells versus non-CSC cells (Table 3). Previous studies, indeed, have revealed important roles for $G$ proteins and $G$ proteincoupled receptors in regulating stem cell function. For instance, signaling mediated by $G$ proteins has been shown to regulate pluripotency/differentiation in mouse embryonic stem cells or human hematopoietic stem cells and affect the morphology and organization of inducible pluripotent stem cell colonies [41-43]. In addition, many of the pathways downstream of G protein signaling directly regulate, or are synergistic with, the pathways that are critical in regulating stem cell pluripotency and differentiation, such as SMAD/Nanog signaling, PI3K/ AKT, MAP kinase/cJun/cFos as well as GSK3/ $\beta$-catenin [44]. Thus, it is not surprising that small G proteins are implicated as regulators of pluripotency and differentiation in diverse stem cell populations.

Lastly, a number of differentially expressed proteins identified by proteomic analysis may have functions related to development or differentiation (Table 4). For instance, we found that the expression of carcinoembryonic antigen-related cell adhesion molecule 6 (CEACAM6) was elevated in CSC-like UM1 cells. Previous studies indeed demonstrated that CEACAM6 is a novel marker for colorectal cancer stem cells [45] and may serve as a potential therapeutic target for pancreatic adenocarcinoma [46]. Significant over-expression (sevenfold) of desmoglein 3 (DSG3) was also observed in CSClike UM1 cells. The functional role and clinical utility of DGS3 in head and neck cancer have been studied previously. Chen et al. found that the expression levels of DSG3 were correlated with clinicopathologic features of head and neck tumors and DSG3-positive cancer cells represented a more aggressive cancer phenotype [47]. Ferris et al. discovered that DSG3 (also known as, pemphigus vulgaris antigen) is a highly valuable biomarker for detection of lymph node metastasis in head and neck cancer. Combining sentinel node biopsy with qPCR testing of DSG3/PVA may allow intraoperative staging of HNSCC for treatment decision-making [48-50]. In addition, we found that vimentin, which is a strong indicator of epithelial-mesenchymal transition (EMT), was up-regulated in spherogenic UM1 cells versus nonspherogenic cells (non-CSC:CSC-like $=0.555$, Table 4). This is in line with previous studies which demonstrated 
that gain of EMT promotes the stemness properties of cancer cells. The activation of EMT programs has been associated with the acquisition of stem cell traits by normal and neoplastic cells. The connection between EMT and stem cells seems to indicate that epithelial stem cells express a wide array of mesenchymal markers and EMT programs would seem to provide a ready source of CSCs by enabling the dedifferentiation of the more epithelial cells within carcinomas [51-53].

Our study revealed that the CREB pathway is activated in CSC-like UM1 cells. CREB-1 can be activated by various cellular kinases including ribosomal protein S6 kinase pp90RSK [54], protein kinase C [55], AKT/protein kinase B [56], mitogen- and stress-activated protein kinase (MSK-1) [57], MAPKAP-2 [58], and calcium/ calmodulin kinases [59], subsequently activating CREB in cells. The crucial event in the activation of CREB is the phosphorylation of Ser133 in KID (kinase-inducible domain), which triggers the recruitment of transcriptional co-activators such as CBP and p300 [18]. In the present study, we found that CBP was overexpressed and CREB-1 was highly phosphorylated in spherogenic UM1 cells, suggesting that the CREB pathway is activated in these CSC-like cells. Since the cells were cultured in serum-free medium containing bFGF and EGF, very likely these growth factors up-regulated the expression of kinases such as MSK-1 [18] in a small subset of UM1 cancer cells (CSC-like cancer cells) and subsequently activated CREB-1. However, why EGF and bFGF activate the CREB pathway only in a specific subset of CSC-like UM1 cells but not the other non-CSC cancer cells remains to be further elucidated.

\section{Conclusions}

As a summary, we have found that the highly invasive UM1 oral cancer cell line harbors a subset of CSC-like cancer cells whereas the low invasive UM2 oral cancer cell line does not. By using serum-free medium containing the growth factors bFGF and EGF for cell culture, we were able to enrich and harvest CSC-like UM1 cancer cells. Stem cell markers such as SOX2, OCT4, SOX9 and CD44 were found to be up-regulated whereas HIF$1 \alpha$ and PGK1 were down-regulated in the CSC-like cells compared to non-CSC cells. Comparative proteomic analysis revealed that many proteins on cell cycle, metabolism, small G protein signal transduction, translational elongation, development, and RNA splicing pathways are differentially expressed between the two cell phenotypes. In particular, we found CBP was over-expressed and CREB-1 was heavily phosphorylated in CSC-like cells. This suggests that the CREB pathway is activated and may play an important role in maintaining the stemness in the CSC-like cancer cells. There have been few studies on the role of the CREB pathway in stem cell function. Cheng et al. found that CREB is highly expressed in lineage negative hematopoietic stem cells and serves as a critical regulator of normal hematopoiesis and leukemogenesis [60]. To the best of our knowledge, this is the first study reporting a potential role of CREB-1 in solid tumor stem-like cells. However, the main weakness of the current study is that we have not demonstrated that the enriched CSC-like UM1 cells are capable of initiating in vivo tumors. In the future, we will use a xenografted transplantation assay to study if spherogenic UM1 cells enhance tumorigenicity in vivo when compared to non-CSC or parental UM1 cells. We will also investigate if CREB-1 is required for regulating the self- renewal and/or differentiation of oral/head and neck CSC-like cells and how the CREB pathway is activated in the oral CSC-like cells. These studies will confirm that the spherogenic UM1 cells are indeed CSCs and may demonstrate potential targets of therapeutic intervention in oral cancer.

\section{Additional file}

Additional file 1: Table S1. A list of proteins with at least one TMT-labeled and confidently matched peptide. Supplemental material for online publication if needed.

\section{Abbreviations}

ALDH: Aldehyde dehydrogenase; bFGF: Basic fibroblast growth factor; CBP: CREB-1-binding protein; CEACAM6: Carcinoembryonic antigen-related cell adhesion molecule 6; CID: Collision-induced dissociation; CREB-1: CAMP responsive element binding protein 1; CSCs: Cancer stem-like cells; (D)MEM: (Dulbecco's) modified Eagle's medium; DSG3: Desmoglein 3; EGF: Epidermal growth factor; EMT: Epithelial-mesenchymal transition; GO: Gene ontology; HNSCC: Head and neck squamous cell carcinoma; LC-MS/MS: Liquid chromatography with tandem mass spectrometry; MSK-1: Mitogen- and stress-activated protein kinase; OSCC: Oral squamous cell carcinoma; PGK-1: Phosphoglycerate kinase 1; qPCR: Quantitative polymerase chain reaction; TKT: Transketolase; TMT: Tandem mass tagging.

\section{Competing interests}

The authors declare that they have no competing interests.

\section{Authors' contributions}

KM, XJL, SF and SH performed the experiments and analyzed the data. $\mathrm{KM}$ and $\mathrm{SH}$ drafted the manuscript. All authors read and approved the final manuscript.

\section{Acknowledgements}

This work was supported in part by the California TRDRP program, University of California CCRC program, Wendy Case Cancer Research Fund and UCLA Pathology/Dentistry Research Service Award.

Received: 21 May 2013 Revised: 16 September 2013 Accepted: 28 November 2013 Published: 25 December 2013

\section{References}

1. Siegel R, Ward E, Brawley O, Jemal A: Cancer statistics, 2011. CA Cancer J Clin 2011, 61:212-236.

2. Day GL, Blot WJ: Second primary tumors in patients with oral cancer. Cancer 1992, 70:14-19.

3. Lippman SM, Hong WK: Molecular markers of the risk of oral cancer. N Eng J Med 2001, 344:1323-1326.

4. Park BJ, Chiosea SI, Grandis JR: Molecular changes in the multistage pathogenesis of head and neck cancer. Cancer Biomark 2011, 9:325-339. 
5. Clarke MF, Dick JE, Dirks PB, Eaves CJ, Jamieson CHM, Jones DL, Visvader J, Weissman IL, Wahl GM: Cancer stem cells - perspectives on current status and future directions: AACR workshop on cancer stem cells. Cancer Res 2006, 66:9339-9344.

6. Dalerba P, Cho RW, Clarke MF: Cancer stem cells: models and concepts. Annu Rev Med 2007, 58:267-284.

7. Jordan CT, Guzman ML, Noble M: Cancer stem cells. N Eng J Med 2006, 355:1253-1261.

8. Visvader JE, Lindeman GJ: Cancer stem cells in solid tumours: accumulating evidence and unresolved questions. Nat Rev Cancer 2008, 8:755-768.

9. Singh SK, Hawkins C, Clarke ID, Squire JA, Bayani J, Hide T, Henkelman RM, Cusimano MD, Dirks PB: Identification of human brain tumour initiating cells. Nature 2004, 432:396-401

10. Ricci-Vitiani L, Lombardi DG, Pilozzi E, Biffoni M, Todaro M, Peschle C, De Maria R: Identification and expansion of human colon-cancer-initiating cells. Nature 2007, 445:111-115.

11. Shipitsin M, Campbell LL, Argani P, Weremowicz S, Bloushtain-Qimron N, Yao J, Nikolskaya T, Serebryiskaya T, Beroukhim R, Hu M, Halushka MK, Sukumar S, Parker LM, Anderson KS, Harris LN, Garber JE, Richardson AL, Schnitt SJ, Nikolsky Y, Gelman RS, Polyak K: Molecular definition of breast tumor heterogeneity. Cancer Cell 2007, 11:259-273.

12. Clay MR, Tabor M, Owen JH, Carey TE, Bradford CR, Wolf GT, Wicha MS, Prince ME: Single-marker identification of head and neck squamous cell carcinoma cancer stem cells with aldehyde dehydrogenase. Head Neck 2010, 32:1195-1201.

13. Zhang Q, Shi S, Yen Y, Brown J, Ta JQ, Le AD: A subpopulation of CD133+ cancer stem-like cells characterized in human oral squamous cell carcinoma confer resistance to chemotherapy. Cancer Lett 2010 289:151-160.

14. Zhang $P$, Zhang $Y$, Mao L, Zhang Z, Chen W: Side population in oral squamous cell carcinoma possesses tumor stem cell phenotypes. Cancer Lett 2009, 277:227-234.

15. Prince ME, Sivanandan R, Kaczorowski A, Wolf GT, Kaplan MJ, Dalerba P, Weissman IL, Clarke MF, Ailles LE: Identification of a subpopulation of cells with cancer stem cell properties in head and neck squamous cell carcinoma. Proc Natl Acad Sci U S A 2007, 104:973-978.

16. Prince ME, Ailles LE: Cancer stem cells in head and neck squamous cell cancer. J Clin Oncol 2008, 26:2871-2875.

17. Chiou SH, Yu CC, Huang CY, Lin SC, Liu CJ, Tsai TH, Chou SH, Chien CS, $\mathrm{Ku} \mathrm{HH}$, Lo JF: Positive correlations of Oct- 4 and nanog in oral cancer stem-like cells and high-grade oral squamous cell carcinoma. Clin Cancer Res 2008, 14:4085-4095.

18. Mayr B, Montminy M: Transcriptional regulation by the phosphorylationdependent factor CREB. Nat Rev Mol Cell Biol 2001, 2:599-609.

19. Siu YT, Jin DY: CREB - a real culprit in oncogenesis. FEBS J 2007, 274:3224-3232

20. Sakamoto KM, Frank DA: CREB in the pathophysiology of cancer: implications for targeting transcription factors for cancer therapy. Clin Cancer Res 2009, 15:2583-2587.

21. Liu T, Hu J, Li H: iTRAQ-based shotgun neuroproteomics. In Methods in Molecular Biology. volume 566. Clifton, NJ, USA: Humana Press; 2009:201-216.

22. Dayon L, Hainard A, Licker V, Turck N, Kuhn K, Hochstrasser DF, Burkhard PR, Sanchez JC: Relative quantification of proteins in human cerebrospinal fluids by MS/MS using 6-plex isobaric tags. Anal Chem 2008, 80:2921-2931.

23. Ross PL, Huang YN, Marchese JN, Williamson B, Parker K, Hattan S, Khainovski N, Pillai S, Dey S, Daniels S, Purkayastha S, Juhasz P, Martin S, Bartlet-Jones M, He F, Jacobson A, Pappin DJ: Multiplexed protein quantitation in saccharomyces cerevisiae using amine-reactive isobaric tagging reagents. Mol Cell Proteomics 2004, 3:1154-1169.

24. Huang DW, Sherman BT, Lempicki RA: Systematic and integrative analysis of large gene lists using DAVID bioinformatics resources. Nat Protocols 2008, 4:44-57.

25. Nakayama S, Sasaki A, Mese H, Alcalde RE, Matsumura T: Establishment of high and low metastasis cell lines derived from a human tongue squamous cell carcinoma. Invasion Metastasis 1998, 18:219-228.

26. Lee J, Kotliarova S, Kotliarov Y, Li A, Su Q, Donin NM, Pastorino S, Purow BW, Christopher N, Zhang W, Park JK, Fine HA: Tumor stem cells derived from glioblastomas cultured in bFGF and EGF more closely mirror the phenotype and genotype of primary tumors than do serum-cultured cell lines. Cancer Cell 2006, 9:391-403.
27. Zaehres H, Lensch MW, Daheron L, Stewart SA, Itskovitz-Eldor J, Daley GQ: High-efficiency RNA interference in human embryonic stem cells. Stem Cells 2005, 23:299-305.

28. Chang CC, Shieh GS, Wu P, Lin CC, Shiau AL, Wu CL: Oct-3/4 expression reflects tumor progression and regulates motility of bladder cancer cells. Cancer Res 2008, 68:6281-6291.

29. Niwa H, Ogawa K, Shimosato D, Adachi K: A parallel circuit of LIF signalling pathways maintains pluripotency of mouse ES cells. Nature 2009, 460:118-122

30. Hussenet $\mathrm{T}$, Dali S, Exinger J, Monga B, Jost B, Dembelé D, Martinet $\mathrm{N}$ Thibault C, Huelsken J, Brambilla E, du Manoir S: SOX2 is an oncogene activated by recurrent $3 q 26.3$ amplifications in human lung squamous cell carcinomas. PLoS One 2010, 5:e8960.

31. Matheu A, Collado M, Wise C, Manterola L, Cekaite L, Tye AJ, Canamero M, Bujanda L, Schedl A, Cheah KS, Skotheim RI, Lothe RA, López-de-Munain A Briscoe J, Serrano M, Lovell-Badge R: Oncogenicity of the developmental transcription factor sox9. Cancer Res 2012, 72:1301-1315.

32. Vaupel $P$ : The role of hypoxia-induced factors in tumor progression. Oncologist 2004, 9:10-17.

33. Jung Y, Shiozawa Y, Wang J, Wang J, Wang Z, Pedersen EA, Lee CH, Hall CL, Hogg PJ, Krebsbach PH, Keller ET, Taichman RS: Expression of PGK1 by prostate cancer cells induces bone formation. Mol Cancer Res 2009, 7:1595-1604.

34. Zieker D, Bühler S, Ustündag Z, Königsrainer I, Manncke S, Bajaeifer K, Vollmer J, Fend F, Northoff H, Königsrainer A, Glatzle J: Induction of tumor stem cell differentiation-novel strategy to overcome therapy resistance in gastric cancer. Langenbecks Arch Surg 2013, 398:603-608.

35. Baris OR, Klose A, Kloepper JE, Weiland D, Neuhaus JF, Schauen M, Wille A, Müller A, Merkwirth C, Langer T, Larsson NG, Krieg T, Tobin DJ, Paus R, Wiesner RJ: The mitochondrial electron transport chain is dispensable for proliferation and differentiation of epidermal progenitor cells. Stem Cells 2011, 29:1459-1468.

36. Willis N, Wilson R, Hutchison C: Lamin A: a putative colonic epithelial stem cell biomarker which identifies colorectal tumours with a more aggressive phenotype. Biochem Soc Trans 2008, 36:1350-1353.

37. Willis ND, Cox TR, Rahman-Casañs SF, Smits K, Przyborski SA, van den Brandt $P$, van Engeland $M$, Weijenberg $M$, Wilson $R G$, de Bruïne $A$, Hutchison CJ: Lamin A/C is a risk biomarker in colorectal cancer. PLoS One 2008 3:e2988.

38. Cuezva JM, Chen G, Alonso AM, Isidoro A, Misek DE, Hanash SM, Beer DG: The bioenergetic signature of lung adenocarcinomas is a molecular marker of cancer diagnosis and prognosis. Carcinogenesis 2004, 25:1157-1163.

39. Cuezva JM, Krajewska M, de Heredia ML, Krajewski S, Santamaria G, Kim H, Zapata JM, Marusawa H, Chamorro M, Reed JC: The bioenergetic signature of cancer: a marker of tumor progression. Cancer Res 2002, 62:6674-6681.

40. Isidoro A, Martinez M, Fernandez PL, Ortega AD, Santamaria G, Chamorro M, Reed JC, Cuezva JM: Alteration of the bioenergetic phenotype of mitochondria is a hallmark of breast, gastric, lung and oesophageal cancer. Biochem J 2004, 378:17-20.

41. Kronenberg HM: Gs signaling in osteoblasts and hematopoietic stem cells. Ann N Y Acad Sci 2010, 1192:327-329.

42. Layden BT, Newman M, Chen F, Fisher A, Lowe WL Jr: G protein coupled receptors in embryonic stem cells: a role for Gs-alpha signaling. PLOS One 2010, 5:e9105

43. Nakamura K, Salomonis N, Tomoda K, Yamanaka S, Conklin BR: G(i)-coupled GPCR signaling controls the formation and organization of human pluripotent colonies. PLoS One 2009, 4:e7780.

44. Callihan P, Mumaw J, Machacek DW, Stice SL, Hooks SB: Regulation of stem cell pluripotency and differentiation by $\mathrm{G}$ protein coupled receptors. Pharmacol Ther 2011, 129:290-306.

45. Gemei M, Mirabelli P, Di Noto R, Corbo C, laccarino A, Zamboli A, Troncone G, Galizia G, Lieto E, Del Vecchio L, Salvatore F: CD66c is a novel marker for colorectal cancer stem cell isolation, and its silencing halts tumor growth in vivo. Cancer 2013, 119:729-738.

46. Strickland LA, Ross J, Williams S, Ross S, Romero M, Spencer S, Erickson R, Sutcliffe J, Verbeke C, Polakis P, van Bruggen N, Koeppen H: Preclinical evaluation of carcinoembryonic cell adhesion molecule (CEACAM) 6 as potential therapy target for pancreatic adenocarcinoma. J Pathol 2009, 218:380-390. 
47. Chen YJ, Chang JT, Lee L, Wang HM, Liao CT, Chiu CC, Chen PJ, Cheng AJ: DSG3 is overexpressed in head neck cancer and is a potential molecular target for inhibition of oncogenesis. Oncogene 2007, 26:467-476.

48. Ferris RL, Xi L, Seethala RR, Chan J, Desai S, Hoch B, Gooding W, Godfrey TE: Intraoperative qRT-PCR for detection of lymph node metastasis in head and neck cancer. Clin Cancer Res 2011, 17:1858-1866.

49. Ferris RL, Stefanika P, Xi L, Gooding W, Seethala RR, Godfrey TE: Rapid molecular detection of metastatic head and neck squamous cell carcinoma as an intraoperative adjunct to sentinel lymph node biopsy. Laryngoscope 2012, 122:1020-1030.

50. Ferris RL, Xi L, Raja S, Hunt JL, Wang J, Gooding WE, Kelly L, Ching J, Luketich JD, Godfrey TE: Molecular staging of cervical lymph nodes in squamous cell carcinoma of the head and neck. Cancer Res 2005, 65:2147-2156.

51. Scheel C, Weinberg RA: Cancer stem cells and epithelial-mesenchymal transition: concepts and molecular links. Sem Cancer Biol 2012. 22:396-403.

52. Mani SA, Guo W, Liao MJ, Eaton EN, Ayyanan A, Zhou AY, Brooks M, Reinhard F, Zhang CC, Shipitsin M, Campbell LL, Polyak K, Brisken C, Yang J, Weinberg RA: The epithelial-mesenchymal transition generates cells with properties of stem cells. Cell 2008, 133:704-715.

53. Morel AP, Lievre M, Thomas C, Hinkal G, Ansieau S, Puisieux A: Generation of breast cancer stem cells through epithelial-mesenchymal transition. PLoS One 2008, 3:e2888.

54. Xing J, Ginty D, Greenberg M: Coupling of the RAS-MAPK pathway to gene activation by RSK2, a growth factor-regulated CREB kinase. Science 1996, 273:959-963.

55. Yamamoto KK, Gonzalez GA, Biggs WH, Montminy MR: Phosphorylationinduced binding and transcriptional efficacy of nuclear factor CREB. Nature 1988, 334:494-498.

56. Du K, Montminy M: CREB is a regulatory target for the protein kinase Akt/PKB. J Biol Chem 1998, 273:32377-32379.

57. Deak M, Clifton AD, Lucocq LM, Alessi DR: Mitogen- and stress-activated protein kinase-1 (MSK1) is directly activated by MAPK and SAPK2/p38, and may mediate activation of CREB. EMBO J 1998, 17:4426-4441.

58. Tan Y: FGF and stress regulate CREB and ATF-1 via a pathway involving p38 MAP kinase and MAPKAP kinase-2. EMBO J 1996, 15:4629-4642.

59. Matthews R: Calcium calmodulin-dependent protein kinase types II and IV differentially regulate CREB-dependent gene expression. Mol Cell Biol 1994, 14:6107-6116

60. Cheng JC, Kinjo K, Judelson DR, Chang J, Wu WS, Schmid I, Shankar DB, Kasahara N, Stripecke R, Bhatia R, Landaw EM, Sakamoto KM: CREB is a critical regulator of normal hematopoiesis and leukemogenesis. Blood 2008, 111:1182-1192.

doi:10.1186/scrt386

Cite this article as: Misuno et al:: Quantitative proteomic analysis of sphere-forming stem-like oral cancer cells. Stem Cell Research \& Therapy 2013 4:156

\section{Submit your next manuscript to BioMed Central and take full advantage of:}

- Convenient online submission

- Thorough peer review

- No space constraints or color figure charges

- Immediate publication on acceptance

- Inclusion in PubMed, CAS, Scopus and Google Scholar

- Research which is freely available for redistribution 